\title{
Criminal Antiprofit Laws: Some Thoughts in Favor of Their Constitutionality
}

\author{
Sue S. Okuda $\dagger$
}

In the struggle for stardom, young actors work long hours in Hollywood hoping to be discovered, and aspiring writers labor over manuscripts for years before sending their stories to the big publishing houses of Manhattan. Recently, however, a rather unusual group of unknowns has been catapulted to fortune by both the entertainment industry in Hollywood and the publishing industry in New York. True stories of criminals and their misdeeds have captured the television viewing market, ${ }^{1}$ and books about criminals gear into production before the criminal even goes to trial. ${ }^{2}$

The public's fascination with criminals is part of its curiosity about the successes and misfortunes of notable personalities, including presidents, astronauts, and war lieroes. ${ }^{3}$ The criminal who feeds this curiosity can coinmand hefty financial returns both for herself and the media. ${ }^{4}$ For exainple, when the New York Post ran a story about the arrest of David Berkowitz, the "Son of Sam" killer," the paper sold one million

$\dagger$ B.A. 1976, University of California, Berkeley; third-year student, Boalt Hall School of Law, University of California, Berkeley.

1. See, e.g., Rosenberg, The 'Boys Club' and Trial by TV, L.A. Times, Nov. 6, 1987, (Calendar) at 1 , col. 1 (review of NBC miniseries about Joe Hunt, leader of an affluent investment group, accused of murdering Ron Levin); Waters, A Haunting 'Fatal Vision', Newsweex, Nov. 19, 1986, at 95 (review of NBC ininiseries about Dr. Jeffrey MacDonald, convicted of the murder of his wife and two young daughters); Emporia Update, L.A. Times, Oct. 12, 1986, (Calendar), at 89, col. 1 (battle between the major broadcasting networks to be the first to broadcast Rev. Thomas Bird's crime story); Marching to Emporia, L.A. Times, Aug. 10, 1986, (Calendar), at 20, col. 1 (discussing Rev. Bird's conviction for his wife's inurder and the initial media battle for story rights); 'Stranger: Cold Look at a Killer, L.A. Times, May 3, 1986, (Calendar), at 12, col. 6 (review of NBC television movie about Theodore Bundy, convicted of the murders of two women and a 12-year-old girl and suspected of 36 other sex-related crimes in several states).

2. For example, Dr. MacDonald negotiated and signed a contract for the sale of his crime story with author Joe McGinnis apparently even before MacDonald's inurder trial began. Memorandum of Points and Authorities in Support of Applicatiou for Temporary Restraining Order and Order to Show Cause re Preliminary Injunction at 6, Kassab v. MacDonald, No. C 672 056 (Cal. Super. Ct. L.A. County filed Jan. 8, 1988).

3. Fedler, When Headlines Are Bought, BARRISTER, Fall 1980, at 14.

4. This term is used in this Comment to refer to both the movie industry and the publishing industry.

5. Berkowitz terrorized New York City for over a year with random shootings that left six people dead and seven wounded. Fedler, supra note 3, at 15. 
copies, compared to its regular daily sales of about $600,000 .{ }^{6}$ McGrawHill Book Company later bought the rights to Berkowitz's story in a deal that included a $\$ 250,000$ advance, $\$ 150,000$ profit to the ghost writer, and $\$ 75,000$ to Berkowitz through his court-appointed conservator, Doris Johnsen. ${ }^{7}$

For the criminal, the media, and the curious public, such deals have mutual benefit. The victim of the now-famous and well-paid criminal, however, traditionally receives nothing for his involuntary role in making the criminal famous. At inost, the victim receives a witness fee for testifying in court-provided, of course, that the victim remains alive and capable of testifying after the crime. ${ }^{8}$ At worst, the victim and his fainily must suffer through constant reminders and revelations about the crime presented by the media: The public's taste for these productions about crime and the indirect exploitation of the victim that this involves have not gone unnoticed by either the judicial system ${ }^{9}$ or the media itself. ${ }^{10}$

In response to growing legislative dissatisfaction with criminals' profiting from their notorious crimes, thirty-four states have enacted laws to prevent convicted crimmals from garnering large profits by marketmg their crime stories. ${ }^{11}$ New York was the first state to pass such a

6. Id. A competitor newspaper, the New York Daily News, "sold 2.2 million copies, 350,000 more than usual." Id.

7. Court to Rule on 'Son of Sam' Book, Wash. Post, Jan. 28, 1979, at A22, col. 1.

8. See, e.g., Cal. Penal Code $\S 1329.1$ (West 1982) (providing for witness fees and notice to witness that she is entitled to receive fees). For an analysis of the victim's historical role as witness, see Gittler, Expanding the Role of the Victim in Criminal Actions: An Overview of Issues and Problems, 11 PePperdine L. REV. 117, 121-35 (1984).

9. The sophistication of our society has embellished the field of entertainment to the extent that reading of the "exploits" becomes an acceptable substitute for "live performances in the Roman arena"-witness the mad rush of publishers to obtain the literary and motion picture rights to the last days of the condemned murderer who preferred death by execution to life imprisonment.

In re Berkowitz, 103 Misc. 2d 823, 825, 430 N.Y.S.2d 904, 906 (Sup. Ct. 1979).

10. See On the Springboard of Notoriety, Time, Oct. 12, 1987, at 64 (exploring the ethical dilemma society has created by allowing criminals to profit from the marketing of their stories); Yardley, Mass Media Murder Mania, Wash. Post, Sept. 22, 1986, at C2, col. 1 (quoting an unidentified editor: "We like to think that we are part of a sophisticated literary world, and not in the business of packaging dirt. But dirt sells." "); Sliales, 'Fear' and Loathing, Wasli. Post, Mar. 29, 1980, at C1, col. 5 (review of a television movie about exploitation by the newspaper industry of a criminal's story).

11. As of April 1988, 34 states luad similar antiprofit legislation: ALA. CoDE $\S$ 41-9-80 (1982); Alaska Stat. \$12.61.020 (1984); ARIz. Rev. Stat. ANN. \$ 13-4202 (Supp. 1987); Cal. Civ. Code § 2225 (West Supp. 1988); Colo. Rev. STAT. § 24-4.1-201 (Supp. 1987); ConN. Gen. STAT. ANN. § 54-218 (West 1985); DEL. CODE ANN. tit. 11, § 9103 (1987); FLA. STAT. ANN. § 944.512 (West Supp. 1985); GA. CodE ANN. § 27-3401 (1983); IdAHo CodE § 19-5301 (1987); ILL. ANN. STAT. cl. 70, para. 403 (Smitli-Hurd Supp. 1988); IND. CODE ANN. § 16-7-3.7-2 (West Supp. 1988); Iowa Code ANN. § 910.15 (West Supp. 1988); Kan. StaT. ANN. § 74-7319 (Supp. 1987); KY. Rev. Stat. ANN. § 346.165 (Baldwin 1983); MASs. Gen. Laws ANN. cl. 258A, § 8 (West 1988); Mich. Comp. Laws ANN. $\$ 780.768$ (West Supp. 1988); MiNN. STAT. ANN. $\$ 611$ A.68 (West 1987); MONT. CODE ANN. § 53-9-104(1)(d) (1987); NEB. REV. STAT. § 81-1836 (1987); NEV. REV. STAT. § 217.265 (1986); N.J. STAT. ANN. § 52:4B-28 (West 1986); N.M. STAT. ANN. § 31-22-22 
law. Known as the "Son of Sam" law because it was passed in reaction to the offers to Berkowitz and his attorney for his story rights, ${ }^{12}$ the New York law places a crimmal's profits in an escrow account on behalf of her victims. ${ }^{13}$

Particularly notorious crimes seem to have prompted antiprofit legislation in other states as well. ${ }^{14}$ In California, a statute similar to New York's was proposed and abandoned in $1978 . .^{15}$ Five years later however-the same year that Dan White was paroled from prison for assassinating San Francisco Mayor George Moscone and Supervisor Harvey Milk-California passed its "Dan White" law. ${ }^{16}$ The statute, like its New York counterpart, places a criminal's profits in a constructive trust for her victims. ${ }^{17}$

Public response to the concept of funnelling a criminal's story profit towards compensatimg her victims has been generally mixed. ${ }^{18}$ Many legal commentators, however, are critical of the statutes, arguing that antiprofit laws unconstitutionally infringe first amendment rights. ${ }^{19}$

(1987); N.Y. Exec. LAW § 632-a (McKinney 1982 \& Supp. 1988); OR. ReV. STAT. $\S 147.275$ (Supp. 1988); PA. Stat. ANN. tit. 71, § 180-7.18 (Purdon Supp. 1988); R.I. GeN. Laws § 12-25.1-3 (Supp. 1987); S.C. Code ANN. \$ 15-59-40 (Law. Co-op. Supp. 1987); S.D. Codified laws ANN. § 23A-28A-1 (1988); TENN. Code ANN. § 29-13-202 (1980); Tex. Rev. Civ. STAT. ANN. art. 83091 , 16 (Vernon Supp. 1987); Wash. ReV. Code ANN. $\$ 7.68 .200$ (Supp. 1988); Wis. STAT. ANN. $\S 949.165$ (West Supp. 1988); Wyo. STAT. $\S 1-40-112$ (d) (1988).

12. Senator Emmanuel Gold, the law's sponsor, stated:

It is abhorrent to one's sense of justice and decency that an individual, such as [Berkowitz, ] the forty-four caliber killer, can expect to receive large sums of money for his story once he is captured-while five people are dead, other people were injured as a result of his conduct. This bill would make it clear that in all criminal situations, the victim must be more important than the criminal.

Memorandum of Sen. Emmanuel R. Gold, 1977 New YoRK State Legislative ANNUAL 267.

13. N.Y. ExEC. LAw § 632-a (McKinney 1982).

14. For example, Massachusetts enacted its antiprofit statute after Gerald W. Clemente, a police captain convicted of bank robbery and stealing Civil Service examinations to sell to his friends, wrote The Cops Are Robbers. See Lawmakers Act to Bar Inmates' Book Profits, N.Y. Times, Nov. 1, 1987, at 39, col. 1. Kansas passed its statute soon after the media developed a great interest in Reverend Thomas Bird's murder of both his wife and his mistress' husband. See Marching to Emporia, L.A. Times, Aug. 10, 1986, (Calendar), at 20, col. 1. The Virginia legislature passed its statute soon after publication of Montie Rissell's autobiography, describing Rissell's conviction for the murders of five northern Virginia women. See Rissell Writes a Book Describing His Murders, Wash. Post, Feb. 5, 1978, at C3, col 1.

15. California Assembly Bill No. 2635, filed Feb. 27, 1978, died in the Criminal Justice Committee. Wand, Criminals-Turned-Authors: Victims' Rights v. Freedom of Speech, 18 PuB. ENT. ADVERT. \& Allied FIELDS L.Q. 401, 403 n.9 (Spring 1980).

16. CAL. Clvil CODE $\$ 2225$ (West Supp. 1988). This statute incorporated without change former Civil Code $\$ 2224$.

17. See infra text accompanying notes 25-29.

18. See Kurnit, "Son of Sam" Meets the First Amendment, N.Y.L.J., July 11, 1986, at 5, col. 1; see also Rissell Writes a Book Describing his Murders, Wash. Post, Feb. 5, 1978, at C3, col. 1; Granelli, The Notoriety for Profit Fight, Nat. L.J., Mar. 7, 1983, at 6, col. 2.

19. Wand, supra note 15, at 409-30; Comment, Alabama's Anti-Profit Statute: A Recent Trend in Victim Compensation, 33 ALA. L. REv. 109, 121-39 (1981) [hereinafter Comment, Alabama]; Comment, Crime Victims Compensation Act-Article 8309-1: Texas Compensates Victims of Crime, 
Trial courts in New York have upheld the New York law, but without an analysis of first amendment doctrines. ${ }^{20}$ The only state court to have addressed this issue was a New Jersey superior court which upheld the constitutionality of its antiprofit statute. ${ }^{21}$ The publisher Simon \& Schuster recently filed a constitutional challenge to the New York statute in a federal suit against the New York State Crime Victims Board, the agency charged with admimistering the statute. ${ }^{22}$

California courts have not had the opportunity to review the constitutionality of the California antiprofit statute. Dan White did not sell his story rights before he committed suicide, shortly after his parole. The estate of Harvey Milk had sued White for profits he would have received under Civil Code $\S 2224$, the predecessor statute to Civil Code $\S 2225$ (the general constructive trust statute for profits from wrongful acts) but was denied recovery as a result of a technicality in that statute. ${ }^{23}$

This Comment analyzes the constitutionality of the California statute by assessing its ability to withstand the first amendment challenges

32 BAylor L. Rev. 247 (1980) (authored by Claud Eugene Vance); Comment, Compensating the Victim from the Proceeds of the Criminal's Story-The Constitutionality of the New York Approach, 14 ColUm. J.L. \& Soc. PROBS. 93 (1978) (authored by Richard Allen Inz) [hereinafter Comment, Compensating the Victim]; Comment, Victims' Compensation: Congress Acts to Make Sure Crime Doesn't Pay-Somctimes, 7 Loy. ENT. L.J. 201 (Winter 1987) (authored by Michele Del Russo Murphy); Comment, The Expansion of Victim Compensation Programs: Today's "Son of Sam" Legislation and Its Susceptibility to Constitutional Challenge, 18 U. ToL. L. REV. 155, 174-88 (1986) (authored by Patricia Nicole Gillard) [hereinafter Comment, Expansion]; 1983 California Legislation: Criminal Procedure; Convicted Felons-Story Proceeds and Involuntary Trusts, 15 PAC. L.J. 570 (1984) [hereinafter Criminal Procedure]; Crime Doesn't Have to Pay, Daily Journal, Mar. 26, 1983, at 4, col. 1; Kurnit, supra note 18, at 5, col. 1. But see Comment, In Cold Type: Statutory Approaches to the Problem of the Offender as Author, 71 J. CRIM. L. \& CRIMINology 255 (1980) (authored by Joel Rothman) [hereinafter Comment, In Cold Type].

20. Barrett v. Wojtowicz, 66 A.D.2d 604, 615, 414 N.Y.S.2d 350, 357 (App. Div. 1979) (discussing and upholding constitutionality of New York statutory period for bringing suit); In re Berkowitz, 103 Misc. 2d 823, 830, 430 N.Y.S.2d 904, 909 (Sup. Ct. 1979) (upholding the law's constitutionality as applied to Berkowitz's conservator); Heath v. Warner Communications, Inc., No. 85 Civ. 1269 (S.D.N.Y. May 27, 1986) (LEXIS, Genfed Library, Dist. file) (a state court's "sub silentio" finding of constitutionality was res judicata in this subsequent claim).

21. Fasching v. Kallinger, No. L-069197-83 (N.J. Super. Ct. Law Div. July 24, 1985), rev'd on other grounds, 211 N.J. Super. 26, 510 A.2d 694 (App. Div. 1986) (question of constitutionality not addressed on appeal). But see Fasching v. Kallinger, 227 N.J. Super. 270, 546 A.2d 1094 (App. Div. 1988) (holding that antiprofit statute will not be applied retroaetively).

22. Complaint for Declaratory and Injunctive Relief at 11-12, Simon \& Schuster, Inc. v. Zweibel, No. 87 Civ. 5582 (S.D.N.Y. filed Aug. 3, 1987). This suit is based on the order from the Crime Victims Board holding that Simon \& Schuster's successful book Wiseguy, the story of former mobster turned informant Henry Hill, is subject to the statute and requiring that the publisher turn over to the Board \$96,250 paid to Hill's literary agent on Hill's behalf. Id. at 9-10; see also Giordano, Publishers Plan Atıack on Son of Sam Law, Manhattan Law, July 12-18, 1988, at 1, col. 2 (update on status of the litigation).

23. CAL. CIV. CODE $\S 2224$ (West 1985). The action failed because former Civil Code $\S 2224.1$ and Probate Code $\S 573$ did not allow beneficiaries of a will to claim the proceeds of an involuntary or constructive trust. The new section allows claims by will beneficiaries. CAL. Crv. CODE $\S 2225$ $(\mathrm{a})(4)(B),(c)$ (West Supp. 1988). 
raised against the New York statute. Part I outlines the provisions of California's antiprofit statute. It then examines the soundness of the statutory remedy as apphed to crime story profits, rejecting a distinction sometimes drawn between seizing profits earned by means of an act which is not wrongful in itself-such as writing a book or a film-and seizing insurance proceeds some murderers would otherwise receive as a result of their victims' deaths. ${ }^{24}$

Part II examines the constitutional challenges of free speech, prior restraint, and vagueness as applied to the California statute. This Part identifies differences between the California and the New York statutes that make the fornier less vulnerable to constitutional challenges than the latter.

Part III explores problems in the application and enforcement of the California statute. It considers the propriety of applying the statute ouly to persons convicted of violent crimes and proposes extending the statute to include profits earned by white-collar criminals. It also explores the impact of the statute on California's entertainment industry and suggests that for the statute to be truly effective, better enforcement is necessary to control producers who attempt to circumvent the law.

\section{I}

\section{Is the Constructive Trust a Good IDEA?}

\section{A. Provisions of the California Statute}

The California statute places in a constructive trust $\mathrm{t}^{25}$ the proceeds ${ }^{26}$ one receives from the sale ${ }^{27}$ of the story ${ }^{28}$ of a felony for which he has been convicted. The statute provides for compensating victims out of the trust for physical, mental, or emotional mjuries, or pecumary losses

24. See Criminal Procedure, supra note 19, at 573 n.36 (noting distinction between the original wrongful act and the subsequent depiction).

25. See infra Part IIB. for a discussion of the constructive trust doctrine.

26. Civil Code $\$ 2225(a)(9)$ provides:

Proceeds" means all fees, royalties, real property, or other consideration of any and every kind or nature received by or owning [sic] to a felon or his or her representatives for the preparation for the purpose of sale of materials, for the sale of the rights to materials, or the sale or distribution by the convicted felon of materials whether earned, accrued, or paid before or after the conviction. It includes any interest, earnings, or accretions upon proceeds, and any property received in exchange for proceeds.

Civil Code $\$ 2225(a)(6)$ provides:

"Materials" means books, magazine or newspaper articles, movies, films, video tapes, sound recordings, interviews or appearances on television and radio stations, and live presentations of any kind.

27. 'Sale' includes lease, license, or any other transfer or alienation taking place in Califoruia or elsewhere." Id. §2225(a)(8).

28. "' 'Story' means a depiction, portrayal, or reenactment of a felony and shall not be taken to mean a passing mention of the felony, as in a footnote or bibliography." Id. $§ 2225$ (a)(7). 


\section{resulting from the convicted felon's crime. ${ }^{29}$}

Anyone who seeks to recover such damages ${ }^{30}$ must file a claim against the constructive trust. ${ }^{31}$ The statute's limitations period supersedes any otherwise applicable statute of limitations for suits claiming civil damage resulting from the crime. ${ }^{32}$ Claims must be filed within five years after the felon receives payment or five years after the date of conviction, whichever is later. ${ }^{33}$ The trust continues until all claims are resolved. ${ }^{34}$ The claims of the beneficiaries, to the extent that they exceed ten percent of the trust fund, ${ }^{35}$ are subrogated to any court-imposed restitution or penalty, any recoverable costs of the criminal's defense by a governmental entity, and the criminal's reasonable attorney's fees in the trial, appeal, or related proceeding. ${ }^{36}$

The attorney general also may bring a court action to impose an express trust on a convicted felon's proceeds within six months after the felon is convicted or has received payment under a covered contract, whichever is later. ${ }^{37}$ At the hearing, the attorney general must establish that the proceeds received by the convicted felon-or her representative-are subject to an involuntary trust and that it is inore probable than

29. Id. $\$ 2225(\mathrm{a})(4)(\mathrm{A})$.

30. Such a person is deemed a "beneficiary", which includes a person who, "under applicable law, other than the provisions of section 2225 , has or had a right to recover damages from the convicted felon for physical, mental or emotional injury, or pecuniary loss proximately caused by the convicted felon as a result of the crime for which the felon was convicted." Id. If the beneficiary has died, the term used here also includes persons designated under section 573 of the Probate Code as entitled to recover damages. Id. $\S 2225(\mathrm{a})(4)(B)$. If the person injured as a result of the convicted felon's crime has died, and the death was proximately caused by that crime, "beneficiary" includes persons designated by section 377 of the Code of Civil Procedure, and any beneficiary under the decedent's will who had the right to receive more than $25 \%$ of the value of the decedent's estate. Id. $\S 2225(\mathrm{a})(4)(\mathrm{C})$.

31. Id. $\S 2225(\mathrm{c})(1)$.

32. Id. $\S 2225(\mathrm{~b})$, (h). California has avoided the statute of limitations ambiguity present in the New York statute. Drafters of the New York statute, N.Y. ExEc. LAw § 632-a (McKinney 1982 \& Supp. 1988), did not originally contemplate that the receipt of proceeds may occur after the tolling of the civil suit statute of limitations and wrote the statute to require the 632-a action to be brought within 5 years of commission of the crime, $i d . \S 632-a(1)$, while allowing the escrow account into which the proceeds were placed to continue for 5 years. Id. $\S 632-\mathrm{a}(4)$. The statute was amended in 1978 to provide that the statute of limitations for a 632-a action would commence when the escrow account was established, thus bringing it into conformity with the rest of the statute. See N.Y. ExEC. LAW $\S 632$-a (historical note), at 180, n.1 (McKinney 1982); Barrett v. Wojtowicz, 66 A.D.2d 604, 611-12, 414 N.Y.S.2d 350, 355 (App. Div. 1979).

33. Cal. Civ. Code $\S 2225(b)$ (West Supp. 1988).

34. Id.

35. Id. $\S 2225(\mathrm{~d})$.

36. Id. Interestingly, the California statute places no dollar ceiling on the amount of money that can be used by the felon for attorney fees, requiring only that they be reasonable. Id. In contrast, the New York statute and several others based on that model limits the amount of proceeds that a felon may use for payment of her attorney fees to a specified percentage. N.Y. ExEC. LAW $\S 632-a(8)$ (McKinney 1982) (one-fifth of the escrow money may be used for legal counsel).

37. CaL. C1v. Code $\S 2225(\mathrm{e})(2)$ (West Supp. 1988). 
not that there are beneficiaries for whom the trust should be established. ${ }^{38}$ The court may impose a preliminary injunction barring the felon's use of covered funds ${ }^{39}$ if it finds that the funds are likely to be subject to the statute and that the possibility of "waste" exists. ${ }^{40}$

The court makes final disposition of the trust to the beneficiary. If no beneficiaries file claims against the trust within the five year trust period, the convicted felon receives the trust funds. ${ }^{41}$

\section{B. Soundness of the Constructive Trust Remedy as Applied to the Proceeds Received by a Criminal for the Sale of Her Crime Story}

The constructive trust is an equitable remedy, whose purpose "is to prevent unjust enrichment and to prevent a person from taking advantage of his own wrongdoing"42 while at the same time compensating victiins of wrongdoing for harms they have suffered. Civil Code $\S 2225$ was enacted as a specialized application of California's general antiprofit legislation, codified as Civil Code $\S \S 2223$ and $2224 .{ }^{43}$ It differs principally in its separate statute of limitations provision and its broader scope of beneficiaries who may claim interest in the trust. ${ }^{44}$

The constructive trust remedy of $\S 2224$ has traditionally been applied to prevent a life insurance beneficiary from receiving the policy proceeds if she is found guilty of murdering the insured. Section 2224 operates to give the beneficiary title to the life insurance policy, but makes her hold the proceeds in trust for the heirs of the victim. ${ }^{45}$ Section

38. Id. $\S 2225(\mathrm{e})(3)$.

39. Id. $\S 2225(\mathrm{f})$.

40. Section 2225 does not contain an explanation of the term "waste." Injunctions can generally be issued when a plaintiff has shown "irreparable injury" to the affected property. Courts have interpreted this as including the wrongful dissipation of financial assets to which more than one party presents a claim. See, e.g., Wind v. Herbert, 186 Cal. App. 2d 276, 8 Cal. Rptr. 817 (Ct. App. 1960) (injunction granted pending accounting of partnership assets).

41. Cal. Civ. Code § 2225(e)(3) (West Supp. 1988).

42. Nevarez v. Nevarez, 202 Cal. App. 2d 596, 602, 21 Cal. Rptr. 70, 74 (Ct. App. 1962); see also 7 B. Witkin, Summary of California Law Con. Law $\$ 131$ (8th ed. 1974).

43. Civil Code $\$ 2223$ provides, "One who wrongfully detains a thing is an involuntary trustee thereof, for the benefit of the owner." Section 2224 provides, "One who gains a thing by fraud, accident, mistake, undue influence, the violation of a trust, or other wrongful act, is, unless he or she has some other and better right thereto, an involuntary trustee of the thing gained, for the benefit of the person who would otherwise have had it." The historical note attached to $\$ 2224.1$, the predecessor of $\S 2225$, states that "this act amplifies, supplements and . . is declaratory of existing law as contained in section 2224."

44. The estate of Harvey Milk was unsuccessful in its suit partially because beneficiaries under a will are not heirs who can claim damages from wrongful death under California Civil Procedure Code $\$ 377$ (only heirs by intestate succession can claim wrongful death damages). Civil Code $\$ 2225$ includes heirs under a will. See supra note 30 .

45. See Beck v. West Coast Life Ins. Co., 38 Cal. 2d 643, 645, 241 P.2d 544, 545.56 (1952); Brazil v. Silva, 181 Cal. 490, 495, 185 P. 174, 176 (1919); Saltares v. Kristovich, 6 Cal. App. 3d 504, 
2224 has also been applied to prevent a murderer from inheriting property froin her victim. ${ }^{46}$

The constructive trust rule of $\S 2224$ is, however, superficially distinguishable from that of $\S 2225$ both in its justification and its structure. First, the constructive trust in the insurance cases acts as a deterrent, discouraging the beneficiary who would be motivated to kill the insured by already in-place financial rewards flowing froin the insured's death. The possibility of a profit from the sale of one's crime story is, however, so speculative that it is unrealistic to suppose one would be deterred from committing a crime by the constructive trust statute. Second, in the insurance murder cases, the constructive trust prevents the beneficiary from directly profiting by her unlawful act. In the crime story cases, however, the criminal technically receives her profits only from entering a lawful contract, and not by committing an unlawful act.

These differences between the two antiprofit provisions do not, however, show $\S 2225$ to be an unsound response to criminals selling the rights to their stories. Although crime story profits are paid pursuant to a lawful contract, the criminal's wrongful act contributed essentially to his financial gain. Moreover, it does serve other important social functions. Specifically, while $\S 2225$ does not deter (indeed few criminals contemplate that they will be caught), the constructive trust better vindicates society's interest in compensating crime victims for a criminal's wrongful act ${ }^{47}$ than does the traditional common law civil damages suit. The constructive trust statute both preserves a known and identifiable

516-17, 85 Cal. Rptr. 866, 873-74 (Ct. App. 1970); Whitfield v. Flaherty, 228 Cal. App. 2d 753, 75557, 39 Cal. Rptr. 857, 858-60 (Ct. App. 1964); Abbey v. Lord, 168 Cal. App. 2d 499, 506-07, 336 P.2d 226, 231-32 (Ct. App. 1959) (same principle applies to division of stock); 7 B. WITKIN, supra note 42, Trusts $\S 133$ (1984 Supp.).

46. New York Life Ins, Co. v. Cawthorne, 48 Cal. App. 3d 651, 121 Cal. Rptr. 808 (Ct. App. 1975) (interaction of Civil Code $\S \S 2224$ and 3517 and Probate Code $\S 258$ covering inheritance by will or intestate succession), Johansen v. Pelton, 8 Cal. App. 3d 625, 632-633, 87 Cal. Rptr. 784, 789. 90 (Ct. App. 1970) (murderer of joint tenant may not succeed to victim's interest), Estate of Helwinkel, 199 Cal. App. 2d 283, 288, 18 Cal. Rptr. 473, 476 (Ct. App. 1962) (convicted murderer not entitled to statutory family allowance from victim's estate); see also Comment, One Way to Insure Inheritance Is Murder, or Is It?, 21 VAL. U.L. REv. 763, 766 (1987) (authored by Tina Nommay) (before state statutes precluded a beneficiary from collecting if he murdered the insured, some courts imposed a constructive trust on the proceeds); $c$. Penn, Deadly Policies Murder for Insurance, A Crime Hard to Solve, Seems to be Growing, Wall St. J., Jan. 14, 1988, at 1, col. 1 (discussing increase in cases where beneficiaries are suspected of murder and the difficulty of proving it).

47. Several commentators have contended that this last result, meeting the victim's expectations of redress from the state, is a fundamental element in today's criminal justice system. Since modern society forbids the private citizen from personally extracting revenge for crimes, the state must take over this role. Schafer, Victim Compensation and Responsibility, 43 S. CAL. L. REv. 55, 58 (1970) [hereinafter Schafer, Victim Compensation]; see also Wolfgang, Victim Compensation in Crimes of Personal Violence, 50 MINN. L. REv. 223, 227 (1965) (reviewing early criminologists Enrico Ferri's and Garofalo's theory that victim compensation should be viewed as a public rather than an individual responsibility); Lamborn, Remedies for the Victims of Crime, $43 \mathrm{~S}$. CAL. L. REv. 
asset of a criminal from which a victim can collect and preserves a victim's claim until the creation of such an asset. Civil actions are often not brought because the offender has no assets from which to pay a judgment. ${ }^{48}$ If the offender later acquires assets, a new action is foreclosed by the statute of limitations. The constructive trust allows a criminal to acquire assets, preserves such assets until his victims can file claims, and then provides the victims the opportunity to file claims regardless of when the crime occurred.

The constructive trust is thus an efficient, appropriate reniedy for victims of crime whose suffering provided a basis for the criminal to be enriched. It enforces the well-recognized legal maxim that a person not profit froin her wrongful act and at the same time satisfies the victim's personal need for some recognition in the criminal justice system. Application of the remedy to the victions of crime is consistent with the unjust enrichment goal of the constructive trust doctrine as developed in Cahifornia.

\section{II}

\section{FIRST AMENDMENT ANALYSIS}

\section{A. The Constructive Trust's Deterrent Effect on Speech Is Insufficient to Implicate First Amendment Interests}

Several commentators have analyzed the constitutionahity of antiprofit statutes under the first amendment of the United States Constitution. ${ }^{49}$ Although their approaches vary, most commentators agree that these statutes unconstitutionally infringe criminals' free speech rights. A criminal's expression, commentators have argued, deserves first amendment protection because it adds to the "marketplace of ideas"so by pro-

22 (1970) (surveying both public and private remedies currently available to victims of violent crimes).

To the victim, criminal justice may appear to be socialized revenge. Schafer, Restitution to Victims of Crime-An Old Correctional Aim Modernized, 50 MINN. L. REv. 243, 244 (1965) [hereinafter Schafer, Restitution]. Thus, in this society where members have surrendered the personal vendetta and family feud to the power of the state to punish, Wolfgang, supra, at 225, society owes the victim the "sense of justice [that arises] . . . in requiring the person who causes damage to repair it, so that neither victims nor third parties are further inconvenienced." Lamborn, supra, at 27 (footnotes omitted).

48. R. Reiff, The Invisible Victim: The Criminal Justice System's Forgotten RESPONSIBILITY 137 (1979) ("Ninety percent of convicted criminals have annual incomes of less than $\$ 5000$. . . O Over half of all convicted felons are unemployed at the time of arrest.").

49. See sources cited supra note 19.

50. Comment, Compensating the Victim, supra note 19, at 105-22; see also Wand, supra note 15, at 411-17 (New York statute infringes on the first amendment rights of the accused and of the other contracting party). The "marketplace of ideas" rationale for freedom of expression is but one of four philosophical rationales for the first amendment. The others are participation by the public in the governmental process, see A. MEIKLEJohn, Political Freedom 8-28 (1960), selfrealization, see Redish, The First Amendment in the Marketplace: Commercial Speech and the 
viding the public and the legislature with insights about criminals' mental processes and methods for deterring criminal behavior. ${ }^{51}$ Indeed, the Supreme Court las explicitly stated that criminal conduct is of legitimate public concern and the reporting of crimes cannot be restricted on the basis of its subject matter. ${ }^{52}$

Antiprofit laws effectively deter a criminal from speaking by restricting the criminal's financial incentive to speak. ${ }^{53}$ The Court lias recognized in the past that such a "chilling effect" upon speecli may offend the first amendment; ${ }^{54}$ accordingly, a court cannot inerely ask whether a law directly restricts speecl. In concluding that antiprofit laws are unconstitutional, coinmentators rely lieavily on Buckley v. Valeo, ${ }^{55}$ where the Court invalidated limitations on campaign expenditures. These limitations, in the Court's view, would restrict political speech by reducing the amount, depth, and distribution of political viewpoints presented to the electorate. $^{56}$

The Buckley Court did uphold ceilings on campaign contributions because it thouglit that these limits only minimally restricted a contributor's right to express support for a candidate. ${ }^{57}$ But the Court noted tliat

Values of Free Expression, 39 GEO. WASH. L. REV. 429, 438-43 (1970), and the attainment of truth, see Emerson, Towards a General Theory of the First Amendment, 72 YALE L.J. 877, 881-82 (1963). The marketplace of ideas rationale is the most common justification for publication of the criminal's story. See Comment, Compensating the Victim, supra note 19, at 105-09; Wand, supra note 15, at 410-11; Comment, Expansion, supra note 19, at 181-82.

51. See Wand, supra note 15, at 410-11; Comment, Compensating the Victim, supra note 19, at 108-09; Comment, Expansion, supra note 19, at 181-82; see also Buckley v. Valeo, 424 U.S. 1, 49 (1976) (dissemination of information is central to the funetioning of a democratic society).

52. See Cox Broadcasting v. Cohn, 420 U.S. 469, 492 (1975) (stating that crimes are of legitimate concern to the public and thus fall within the responsibility of the press to report); Comment, Expansion, supra note 19, at 182.

53. See Giordano, supra note 22, at 34 , col. 3 (Nicholas Pileggi states that Henry Hill, a former member of organized crime turned informant, would not have agreed to work with him on his story if Hill could not be compensated); Roberts, Criminal, Authors and Criminal Authors N.Y. Times, March 22 1987, Book Review section at 1, 34 (quoting R. Foster Winans, author of Trading Secrets: Seduction and Scandal at the Wall Street Journal, who was convicted of insider trading as saying, "There would have been a strong economic disincentive if I had thought the law would have applied.") [hereinafter Roberts]; see also Wand, supra note 15, at 413-14 (under antiprofit statutes, funds are denied criminal when the need to adequately exercise freedom of speech is greatest); Comment, Alabama, supra note 19, at 127-30 (laws deprive offender of expected profits and resources necessary to communicate). But cf. Comment, Expansion, supra note 19, at 185 (the first amendment does not confer a right to be compensated for expression).

54. Gibson v. Florida Legislative Investigation Comm., 372 U.S. 539, 556-57 (1963) (court feared "chilling effect" on freedom of association if investigation committee were given access to NAACP membership list); see also Freedman v. Maryland, 380 U.S. 51, $60-61$ (1965) (requirement that motion pictures be submitted to censors before screening lacked adequate safeguards to prevent the undue inhibition of protected speech).

55. 424 U.S. 1 (1976).

56. Id. at 21; see Wand, supra note 15 , at $413-14$; Comment, Alabama, supra note 19 , at 128 29.

57. Buckley, 424 U.S. at $20-21$. 
ceilings on campaign contributions might be unconstitutional too if their effect was to prevent the collection of funds necessary for effective communication. ${ }^{58}$ One commentator has noted that this dictum may apply to antiprofit laws as well because they keep criminals from amassing the resources necessary for effective speech. ${ }^{59}$

Pubhishers challenging the constitutionality of the New York statute have also argued that it deters speech, relymg on the recent United States Supreme Court case of Meyer v. Grant. ${ }^{60}$ The Meyer Court invalidated a statute that prohibited compensation of individuals who circulate petitions to qualify state ballot initiatives for state elections. ${ }^{61}$ Requiring circulators to work for free, the Court found, unconstitutionally restricted political speech by effectively liniting the number of circulators, therefore linniting the potential audience for a ballot initiative petition. ${ }^{62}$ The Court also noted that the statute inade it less likely that an initiative would be able to garner the signatures necessary to be put on the ballot, thus frustrating the ability of the initiative supporters to focus statewide discussion on the subject of the initiative. ${ }^{63}$ The state's interest in preserving the integrity of the initiative process was insufficient, the Court said, to justify the injury to political speech that would result from the statute. $^{64}$

It cannot be shown that the California antiprofit statute will not decrease the number of criminals who would market their crime stories in its absence. But, the coinmentators' deterrence argument rests on the problematic assumption that the inere possibility of deterrence is enough to invalidate antiprofit statutes on first amendinent grounds. The United States Supreme Court, however, has expressed doubt that a statute's "speculative" deterrent effect can inplicate the first amendnient.

In Branzburg v. Hayes, ${ }^{65}$ the Court held that newspaper reporters could be required to testify before a grand jury about information obtained froln a confidential source, even if the source had supphed the infornuation only on the condition of anonyinity. The journalists argued that disclosure would deter the speech of sources wishing to remain anonynrous. ${ }^{66}$ The Court, however, held that the journalists must show a

58. Id. at 21 ("contribution restrictions could have a severe impact on political dialogue if the limitations prevented candidates and political committees from amassing the resources necessary for effective advocacy").

59. See Wand, supra note 15 , at 414.

60. 108 S. Ct. 1886 (1988); see Giordano, supra note 22, at 34 , col. 5 .

61. $108 \mathrm{~S}$. Ct. at 1889 .

62. Id. at 1892 .

63. Id.

64. Id. at 1894.

65. 408 U.S. 665 (1972).

66. Id. at 679-81. 
"significant constriction of the flow of news to the public."67 From the evidence, the Court could not determine the extent to which informers would actually be deterred. ${ }^{68}$ Some evidence indicated that informers are strongly motivated to speak even with the risk of exposure because of the desire, for example, to publicize their viewpoints. ${ }^{69}$ The Court said that ultimately, even if some informers would not speak to journalists because they feared identification, the public interest in prosecuting crimes outweighs the "public interest in possible future news about crime from undisclosed, unverified sources."

It would be difficult to show that the California antiprofit statute's deterrent effect is more than just speculative. Despite vigorous enforcement of the more encompassing New York statute, several criminals' stories have been written and published in New York since it was enacted. ${ }^{71}$ Similarly, a number of movies subject to California's antiprofit statute have been completed since California passed its statute in $1983 .{ }^{72}$

In fact, criminals, like other speakers, have motivations for speaking besides pecumary gain, and there is some evidence that criminals are willing to sliare their stories for no compensation at all. ${ }^{73}$ Sometimes, for exainple, criminals actually desire to compensate their victims. ${ }^{74}$ In such

67. Id. at 693. The Court's reference to Professor Blasi's report, Press Subpoenas: An Empirical and Legal Analysis, which was included in a study report of the Reporter's Committee on Freedom of the Press, suggests why the grand jury subpoena is not a "significant constriction." After surveying 975 reporters, Professor Blasi found that half relied on regular confidential sources for about ten percent of their stories, but only eight percent of those thought their work had been adversely affected by the grand jury subpoena power over the press. Id. at $694 \mathrm{n} .33$.

68. Id. at $681 \mathrm{n} .20$ and $693 \mathrm{n} .31$ (the record included several affidavits of joumalists detailing their experiences after appearing before grand juries, and numerous studies of the journalist's use of confidential information).

69. Id. at 695 .

70. Id. at 694-95 (the informer is often a member of a "minority political or cultural group [which] relies heavily on the media to propagate its views, publicize its aims and magnify its exposure to the public).

71. Such books include J.H. ABBOTT, IN THE BELLY OF THE BEAST: LETTERS FROM PRISON (1981); S.B. BarrowS, MAYFLoWER MADAM (1986); J. HARRIS, STRANGER IN TWo WorLdS, (1986); F. Schreiber, The Shoemaker: The Anatomy of a Psychotic (1983); N. Pileggi, Wiseguy: Life in a Mafia Family (1985); N. Tosches, Power on Earth (1986); R.F. Winans, Trading Secrets (1986); see also G. Carpozi, Son of SAM (1977); L. Walters, Dog DAY AFTERNOON (1974).

72. See Yardley, supra note 10 (the lawyer for Robert E. Chambers, Jr., who murdered Jennifer Dawn Levin in New York's Central Park in 1986, was approached with over 100 offers for movies or television films within one month of the murder).

73. John Stein, deputy directory of the National Organization for Victim Assistance in Washington, D.C., has stated, " 'Accomplished writers spending a year or two or three on a single book, like Peter Maas or Gay Talese, have proven to the world that you don't have to pay these scumbags-they'll tell you anyway, if you're a hardworking, honest journalist." " Snider, Coming Soon to a Theatre Near You, 7 CAL. LAw. 28, 31-32 (April 1987).

74. Gary Gilmore requested several times before he was executed that a portion of the proceeds from any stories about his life and crime be distributed to the families of his victims. N.Y. Times, Jan. 18, 1977, at 21, col. 4. Montie Rissell wants to use some of the proceeds from his book 
cases, antiprofit laws would encourage speech rather than deter it. Criminals may also be motivated to speak by a desire to publicize their side of the story, retrying the case that they lost in the court of public opinion.

A criminal may also enter a media contract to raise money for her most pressing need, her criminal defense. The California statute allows the criminal to use her crime story profits to pay private counsel fees. ${ }^{75}$ It also allows the criminal to use her profits to pay court-imposed fines ${ }^{76}$ and restitution that is ordered as a condition of probation. ${ }^{77}$ By making the profits from speech available to the criminal for these purposes, the statute provides an important incentive for speech that minimizes any deterrent effect.

Furthermore, antiprofit statutes do not impede access to effective media of cominunication for criminals who want to tell their story. While authors may generally rely on contract advances to cover their research and other prehminary expenses, ${ }^{78}$ the criminal has no similar need for funds in advance of publication, because he typically sells only his rights to his story, not his services as author. In practice, a paid ghostwriter commonly pens the criminal's story. ${ }^{79}$

The statute leaves in place the financial incentives of publishers, producers, and ghostwriters to pursue the rights to criminals' stories. As interpreted, the statute does not prohibit the publisher or producer from retaining its profits from the sale of a criminal's story, nor does it deprive a writer who is herself not the criminal from retaining profits earned by writing the criminal's story. ${ }^{80}$

The California statute also has procedural protections that prevent abuse of the constructive trust remedy at the expense of the crininal's first amendment interests. ${ }^{81}$ First, a trust clainiant must obtain a civil

to pay his victims. Rissell Writes $A$ Book, supra note 14, at C3, col. 1. Professor Schafer surveyed inmates in a Florida prison and found that those convicted of homicide felt the most remorse for their crimes. Schafer postulates that the criminals' reflection over their own mortality as they await execution may account for these attitudes. Among those convicted of lesser crimes, including aggravated assault, robbery, and burglary, the percentage who felt compassion for their victims was dramatically lower. Schafer, Restitution, supra note 47, at 250-51 (1965).

75. Cal. Civ. Code $\$ 2225$ (d) (West Supp. 1988).

76. The California victims compensation laws require a court to impose on a convicted criminal an additional restitution fine of $\$ 100$ to $\$ 10,000$. CAL. GovT. CodE $\$ 13967$ (a) (West 1980 \& Supp. 1988).

77. Cal. Civ. Code $\S 2225$ (d) (West Supp. 1988).

78. Wand, supra note 15 , at 413 .

79. See Ghostwriters Leave the Closet for the Dust Jacket, N.Y. Times, Feb. 26, 1985 at 17, col. 1 (describing writers' contracts with criminals).

80. See CAL. CIV. CODE $\$ 2225(a)(1)$ (statute applies only to profits earned by the "convicted felon") (West Supp. 1988)

81. The Branzburg Court emphasized procedural protections which prevented abuse of the grand jury subpoena power. Branzburg v. Hayes, 408 U.S. 665, 706-08 (1972). 
judgment to establish an interest in the trust, ${ }^{82}$ thereby protecting the trust for the criminal against undeserving claimants. ${ }^{83}$ Second, the state Inust prove in a court action with a full evidentiary hearing the propriety of establishing an express trust for the proceeds of a criminal author's story. ${ }^{84}$ The state cannot establish an express trust by administrative proceedings or ex parte hearings that might be thought to pave the way for excessive use of the express trust. ${ }^{85}$

The California statute thus contains incentives and procedural safeguards which minimize any deterrent effect on a criminal's telling his story. However, even if the statute's purported deterrent effect warrants first amendment scrutiny, the statute should still survive under current free speech analysis. The statute here is justified because it is directed only at the secondary effects of a criminal's speech-that is, his deriving unjust enrichment at the expense of his victims-and not at the speech itself. The Supreme Court has in the past distinguished between a statute's primary and secondary effects, sustaining statutes which regulated only secondary effects of speech.

In City of Renton $v$. Playtime Theaters, ${ }^{86}$ a zoning ordinance restricted the location of adult novie theaters. Even though this ordinance singled out adult theaters from other theaters, the City did not justify the ordinance as a ineans of suppressing adult movies. Rather, Renton justified the ordinance on the basis of the effects that adult theaters have on crime. ${ }^{87}$ The Couri said that since Renton's ordinance was aimed at only the secondary effects of speech it could be sustained if the City had a substantial interest at stake, the ordinance served the interest by the least restrictive means, and it allowed for reasonable alteruative avenues of communication. ${ }^{88}$ Following its opinion in Young v. American Mini Theaters, ${ }^{89}$ the Court found that Renton's interest in preserving the quality of urban life was sufficiently substantial to justify the regula-

82. CAL. Civ. CODE § 2225(c)(1)-(3) (West Supp. 1988).

83. Unlike the California law, the New York statute requires the publisher to determine whether the work is subject to the statute, and thus whether the criminal author's fees should be paid into an escrow account. If the publisher guesses wrong and pays the author, it could be subject to double liability. Also, an administrative board rather than a court first determines whether the statute encompasses a particular work. Commentators have criticized the New York statute on both of these grounds. See Wand, supra note 15, at 426-65; Comment, Compensating the Victim, supra note 19 , at 105 .

84. CAL. CIV. CoDe § 2225(e)(1) (West Supp. 1988).

85. Cf. Comment, Compensating the Victim, supra note 19, at 99-105 (discussing procedural shortcomings of the New York law).

86. 475 U.S. 41 (1986).

87. Id. at 47 .

88. Id. at 50 .

89. 427 U.S. 50, 70-71 (1976) (city regulation controlling location of adult theaters was valid due to the state's "adequate" interest in protecting charaeter of neighborhoods). 
tion. $^{90}$ The statute was narrowly tailored to affect only that category of theaters that threatened the quality of urban community life. ${ }^{91}$ And since the City allowed adult theaters on several hundred acres of land, ${ }^{92}$ there were reasonable alternative avenues of communication. In response to the argument that this land was economically unsuitable for adult theaters, the Court said that the first amendment does not immunize theaters from competing with other busmesses on the open market for space, but requires only that a city allow theaters the opportumity of opening within its boundaries. ${ }^{93}$

The antiprofit law is analogous to the zoning ordinance in Renton. ${ }^{94}$ Like the zonmg ordinance, the antiprofit law focuses on a distinct class of speakers. However, the purpose of the statute is not to suppress the content of their speech, but to justly distribute profits from crimmals' speech-ensuring victims' recovery of tort damages when criminals are enriched as a result of their illegal acts. A victim who receives a tort judgment against a criminal can, at common law, procure a lien on the criminal's assets, without differentiation among the sources of those assets. The antiprofit law simply implements a special procedure for preserving a victim's cause of action against a criminal until the criminal has an asset from which to collect a judgment. Since the criminal's story rights are one of her more valuable assets, targeting that asset for the victim's recovery is an efficient means of ensuring that the victim will be compensated. Ultimately, in helping victims recover against crimmals, the statute not only prevents a criminal's unjust enrichment, but also it: (1) decreases the likelihood that society will have to support victims of crime through social programs; ${ }^{95}$ (2) satisfies victims' sense of justice and desire for retribution; ${ }^{96}$ and (3) increases the crimmal's awareness of the consequences of his crime. ${ }^{97}$

Second, the statute is narrowly tailored. The statute affects only

90. 475 U.S. at 50 (citing American Mini Theaters, 427 U.S. at 71).

91. Id. at 52 .

92. Id. at 53 .

93. Id. at 54 .

94. Renton has been sharply criticized since its announcement. See G. GUNTHER, CONSTItUTIONAL Law 125 (Supp. 1988) (suggesting that Renton could be used to justify restrictions on any "inflammatory" speech because such statutes are invariably directed toward the "secondary effects" of the communication). However, if it has vitality in any class of cases it would be in situations like the antiprofit law-where the state has no identifiable ulterior motive for deterring the "primary effect" of speech. Indeed, states have a strong interest in criminal expression because it may: 1) inform and improve crime prevention efforts; 2) reinforce law-abiding behavior by expressing contrition or unifying community anticrime sentiment; or 3) serve to rehabilitate the criminal. By contrast, no commentator thus far has identified any reason why the state would wish to chill criminal speech independent of the profits such speech produces for the criminal.

95. Lamborn, supra note 47, at 27.

96. Schafer, supra note 47 , at 59.

97. Lamborn, supra note 47 , at 27. 
convicted felons and not persons who are only accused and later exonerated. In addition, it provides for claims only by those who prove damages "as a result of the crime for which the felon was convicted."98 The statute also specifies that the story which it presented must be the story of the felony for which the felon was convicted. ${ }^{99}$ Finally, although it does differentiate between speakers on the basis of content, it does not differentiate on the basis of their viewpoints-a distinction that the Court has emphasized in upholding regulations affecting speech. ${ }^{100}$

The statute does, of course, risk placing a lengthy hold on the felon's profits. ${ }^{101}$ Even if the statute of limitations on a victim's tort claim has expired before the criminal receives her profits, the antiprofit statute extends the tort statute of limitations, allowing the victim to file a claim to the profits any time within five years of when they are earned. Since some crimmal trials take several years to complete, this could result in a lengthy hold on money to which the criminal is ultimately entitled. This alone, however, does not mean that the statute is not narrowly tailored. Indeed, the legislative history of $\S 2224$ suggests that the extended trust period is necessary to ensure that the victim has sufficient time to claim the proceeds. ${ }^{102}$

Finally, since the statute does not prohibit the criminal's speech, there is no need for an alternative channel of coinmunication. Unlike the theater restriction in Renton, the antiprofit statute leaves every medium of communication available to the criminal. Access to the media is not the focus of the statute. Indeed, the statute comes into play only after access occurs. Thus, the antiprofit statute satisfies the three prongs of the Renton test and may be upheld as a permissible restraint on the secondary effects of speech. ${ }^{103}$

98. CAL. Civ. CoDE § 2225(a)(4)(A) (West Supp. 1988).

99. Id. $\S 2225(\mathrm{~b})$. The scope of the California statute is significantly narrower than the New York statute, which has been criticized as overbroad because it allows recovery of the profits from a story about any crime that a criminal committed. N.Y. ExEC. LAW § 632-a(1) (McKinney 1982); see Wand, supra note 15 , at 426.

100. See Young v. American Mini Theaters, 427 U.S. 50, 70 (1976) (upholding an ordinance regulating the location of adult movie theatres, in part because the ordinance applied to the places where adult films were shown, not the films' viewpoint); see also Greer v. Spock, 424 U.S. 828, 840 (1976) (ban on partisan political activities on military post upheld because not based on the speakers' viewpoint); Lehman v. City of Shaker Heights, 418 U.S. 298, 304 (1974) (viewpoint-neutral ban on political advertising upheld); Comment, In Cold Type, supra note 19 at 265 (content-based, but viewpoint neutral restrictions should survive first amendment scrutiny).

101. CAL. Clv. CODE § 2225(b) (West Supp. 1988).

102. An earlier draft of the bill contained a 10-year commencement period. A.B. 2102 , 96th Leg., Reg. Sess., 1983 California Leg. 96-120. Later versions reduced this period to five years, suggesting that the legislature was concerued with not imposing an undue burden upon assets covered within the statute.

103. See Roberts, supra note 53, at 34, col. 2; Comment, Compensating the Victim, supra note 19 , at 110. 


\section{B. Constructive Trust Is Not a Prior Restraint}

A related first amendment challenge to the antiprofit statutes concerns whether these laws operate as a "prior restraint" upon speech. The doctrine of prior restraint under the first amendment forbids the government from censoring speech in advance of publication. ${ }^{104}$ The doctrine does not address the issue of whether the government can forbid one kind of expression, "but whether it may do so by a particular method, such as advance screening of newspaper copy."105 Therefore, regulations which validly sanction speech after publication may be forbidden if imposed prior to publication. ${ }^{106}$

In Near v. Minnesota, ${ }^{107}$ the Court for the first time invalidated a state law which it felt effectively censored speech through injunction proceedings. ${ }^{108}$ The invalidated statute allowed a state to secure a court order to abate any "malicious, scandalous and defamatory newspaper." 109 Testing the statute by its "operation and effect,"110 the statute proved to be a prior restraint since it would cause a risk-averse publisher either to forego publishing certain material or to clear the material with the judge in advance of publication. ${ }^{111}$ Consequently, "the judge would, in effect, become a censor."112

Claims of prior restraint by publishers and producers who are subject to antiprofit statutes is inappropriate because the antiprofit law does not create, in either the judiciary or an administrative body, the functional equivalent of a censor. The statute does not prohibit publication of a crimmal's story that falls under it at all, let alone without a government official's prior approval. ${ }^{113}$ If, after an adversarial judicial hearing, ${ }^{114}$ a

104. Emerson, The Doctrine of Prior Restraint, 20 Law \& ConTEMP. Probs. 648, 648 (1955).

105. Id.

106. Id.

107. 283 U.S. 697 (1971).

108. Emerson, supra note 104, at 654.

109. See Near, 283 U.S. at 712-13. The publisher of such a target newspaper was permitted to appear in court to clallenge the order, by showing the truth of the matter published and that it "was published with good motives and for justifiable ends." Id. at 711-12. However, requiring the publisher to justify the news on the grounds of truth and good motives was tantamount to establishing a "complete system of censorship". Id. at 721. In this particular case, the likelihood of an improper purpose was clear, because the newspaper had openly criticized public officials. See id. at 704 .

110. Id. at 708.

111. Emerson, supra note 104, at 654.

112. Id.

113. Compare CAL. Civ. CODE $\S 2225$ (b) (West 1988) (allowing proceeds to be seized but not enjoining publication) with the statute in Near, 283 U.S. at 702-03 (labeling a "nuisance" any publication determined to be lewd or malicious and enjoining its publication).

114. See Freedman v. Maryland, 380 U.S. 51, 58 (1965) ("only a judicial determination . . suffices to impose a valid final restraint."). In Freedman, Justice Brennan, writing for the Court, established a judicial procedure to restrict what he perceived as the Court's endorsement of film censorship in Times Film Corp. v. Chicago, 365 U.S. 43 (1961). Brennan required that permit 
criminal's profits are found to fall within the statute, the statute does not require the publisher or producer to forego publishing that criminal's material or to seek approval of the material from a third party before publication. ${ }^{115}$ Nor does the statute force the publisher to risk legal sanctions by publishing materials that might later be determined to come within the statute. ${ }^{116}$ Thus, in operation, the speculative deterrent effect of the statute does not qualify as a prior restraint; the law does not forbid the production of any work but only applies after that work has been contracted for and the contract has received close judicial consideration.

\section{The California Antiprofit Statute Is Not Void for Vagueness}

Critics of the New York statute have contended that it is void for vagueness because it is unclear which contracts are included within its scope. ${ }^{117}$ That statute simply provides that contracts for the "expression of such accused or convicted person's thoughts, feelings, opinions or emotions regarding such crime"118 are subject to it. This uncertainty purportedly affects both the crimmal and his publisher: the criminal, because he will be uncertain whether the state will take money he receives, and the publisher, because it has the burden of submitting contracts to the Crime Victims Board and paying to the Board any money owed the criminal author. ${ }^{119}$

Regardless of whether the foregoing uncertainties rise to the level of unconstitutional vagueness, these arguments apply to the New York statute. The California statute avoids this purported defect by reducing

systems on movie screenings use a quick and final adversarial judicial proceeding, in which the state bears the burden of proving that the speech is unprotected. Id. at 58-59; see also United States v. Thirty-Seven Photographs, 402 U.S. 363, 374-75 (1971) (licensing scheme involving seizure of obscene material by customs officials is valid because it provided for prompt judicial review of the seizures); Kingsley Books, Inc. v. Brown, 354 U.S. 437, 443 (1957) (New York injunction system to prevent the sale of obscene books is valid because it required a judicial determination of obscenity); Southeastern Promotions, 420 U.S. at 559 (applying Freedman standards).

While the possibility of judicial error or indifference to first amendment interests remains, most commentators are not so cynical as to believe that a judge will ignore first amendment jurisprudence as easily as a bureaucratic ceusor might. See, e.g., Mayton, Toward a Theory of First Amendment Process: Injunctions of Speech, Subsequent Punishment, and the Costs of the Prior Restraint Doctrine, 67 CORNELL L. REV. 245, 250-51 (1982) (a court is "accustomed to dealing with a range of societal interests; its basic charge, moreover, is to vindicate constitutional rights."); $c f$. Freedman v. Maryland, 380 U.S. at 57-58 ("[b]ecause the censor's business is to censor, there inheres the danger that he may well be less responsive than a court to the constitutionally protected interests in free expression.").

115. See infra text accompanying note 117 .

116. Cal. Civ. Code $\S 2225$ (a)(1) (West Supp. 1988).

117. Wand, supra note 15, at 427; Comment, Compensating the Victim, supra note 19, at 111-12.

118. N.Y. ExEc. LAw $\S 632-a(1)$ (McKinney 1982).

119. Wand, supra note 15, at 426-27; Comment, Compensating the Victim, supra note 19, at 111-12. But see Comment, In Cold Type, supra note 19, at 264 (arguing that the New York statute is not vagne). 
uncertainty. First, California publishers are not responsible for establishing trusts. Instead, California's trusts come into existence through court proceedings instituted by the state attorney general. A publisher may pay a criminal as it would pay one not subject to the statute, without liability. The criminal, though, receives title to such proceeds only in trust for his victims. The publisher never risks double liability for paying the wrong party, as publishers suggested they did under the New York statute. ${ }^{120}$ Second, the statute is not ambiguous because the criminal author is able to determine whetlier the statute applies to him. The statute applies to all convicted felons who are compensated by contract for telling the story of their crime. ${ }^{121}$ There is no room for the defendant to claim that he did not know he had been convicted of a felony or that he had entered into a contract for the story of that crime. California delineated which contracts are covered under its statute more precisely than New York did, by narrowing New York's category of "any expression ... regarding sucli crime" to "a depiction, portrayal or reenactment of a felony."122 The doubt possible under the New York law over whether a work is emotionally or psychologically expressive of one's crime is less likely under the California law. Therefore, $\mathrm{m}$ avoiding the possibility of double liability and carefully setting out its scope, the California statute should not be found void for vagueness.

\section{III}

\section{Unsolved Problems ANd Proposed Solutions}

\section{A. Victims of White-Collar Crime}

The New York statute as originally enacted was criticized for providing recovery only to victims "who [suffer] personal physical imjury as a direct result of a crime." 123 The statute did not provide a remedy to victims who were emotionally injured by a criminal or who lost money from fraud or embezzlement schemes. White-collar criminals and their victims then were insulated from the New York antiprofit statute. ${ }^{124}$

A New York appellate court subsequently widened the scope of the law by interpreting it to provide for damages to a person wlio suffered no physical injury while held hostage in a bank robbery. ${ }^{125}$ Soon the New

120. See Wand, supra note 15, at 429-30 (arguing that New York statute burdens the publisher by creating uncertainty concerning to whom the proceeds should be paid and thus providing the possibility of double liability if it pays the wrong party); $c$. Comment, In Cold Type, supra note 19 at 264 (arguing that New York statute does not impose a double liability).

121. The statute also applies, of course, to defendants who plead guilty, but it does not apply to defendants who are acquitted. CAL. CIV. CODE § 2225(a)(1) (West Supp. 1988).

122. Id. $\S 2225(\mathrm{a})(7)$.

123. Comment, Compensating the Victim, supra note 19 , at 118.

124. Id.

125. Barrett v. Wojtowicz, 66 A.D.2d 604, 614-15, 414 N.Y.S.2d 350, 356-57 (App. Div. 1979). 
York legislature amended the statute by defining "victim" as "a person who suffers personal, physical, mental, or emotional injury, or pecuniary loss as a direct result of the crime." 126 Compensation no longer depended on the nature of the loss, but extended to any injury shown to be a "direct result" of the crime.

When California enacted its antiprofit statute in 1983, it adopted this broader coverage by defining "beneficiary" as:

a person who, under applicable law, other than the provisions of this section, has or had a right to recover damages from the convicted felon for physical, mental, or emotional injury, or pecuniary loss proximately caused by the convicted felon as a result of the crime for which the felon was convicted. ${ }^{127}$

Although the California statute has yet to be tested judicially, this provision seems to cover victims of white-collar crime as well as violent crime. The victim need only show that he has a claim for damages arising from the underlying felony. Thus, under the Cahfornia statute, the victim of a deceptive proxy statement could recover damages for losses suffered as a result of his reliance on that statement. ${ }^{128}$ Allowing recovery of these proceeds advances the purpose of the statute. Already, many convicted white-collar criminals have successfully marketed their stories. ${ }^{129}$ White-collar crimmals, typically being more literate than other criminals are more likely to want to sell their stories, and, conversely may be more likely to feel punished by economic sanctions. ${ }^{130}$

The Cahifornia statute, while covering victims of white-collar crime, has no application to perpetrators of victimless crimes, in which category many white-collar criminals fall. One approach that treats the unjust enrichment situation consistently would be to amend the statute to provide that, after attorney fees and court-imposed fines are paid, part of a criminal's profit from a victimless crime should be channelled into the state's general victims' compensation fund. The amount put into the

126. N.Y. EXEC. LAW § 632-a(10)(a) (McKinney 1982 \& Supp. 1988).

127. Cal. CIv. CoDe $\S 2225($ a)(4)(A) (West Supp. 1988).

128. See CAL. Corp. CODE $\S 25502$ (West 1977).

129. For example, R. Foster Winans, sentenced to 18 months in prison for leaking to two New York stockbrokers information that would later appear in his Wall Street Journal column and earning \$30,000 in the process, has written Trading Secrets: Seduction and Scandal at the Wall Street Journal published by St. Martin's Press. When the book was released, Winans signed a movie option. N.Y. Times, Oct. 6, 1986, at C17, col. 1.

Only one New York court has discussed the applicability of its antiprofit statute to violent crime. The trial judge in In re Robert Halmi Sr., N.Y.L.J., June 2, 1986, at 12, col. 3, aff'd 128 A.D.2d 411, 512 N.Y.S.2d 650 (1987), held that the statute did not apply to the book, Mayflower Madame, by Sydney Biddle Barrows who was convicted for promoting prostitution. The judge labelled prostitution a victimless crime and noted that any "victims" would have to admit that they themselves committed crimes in order to assert any claim against Barrows' profits. Id.

130. Goldstein, Defining the Role of the Victim in Criminal Prosecution, 52 Miss. L.J. 515, 533 (1982). 
state fund could be based upon the severity of the offense or the related costs of law enforcement: For example, selling military secrets might require a greater amount than prostitution. Such an amendment to the statute would subject all white-collar criminals to the same habilities as the violent criminal offender. Simply because there is no identifiable victim does not mean the white-collar crimmal is not unjustly enriched by the marketing of her crime story. The state should be regarded as the victim's proxy and be allowed to use part of the criminal's profits for the benefit of the state's general crime victims program.

\section{B. Skirting the Law By Indirectly Obtaining the Criminal's Story Rights}

Surprisingly, the entertainment industry did not oppose the California antiprofit bill when it was being debated. ${ }^{131}$ However, since its enactment, the industry has adopted several clever tactics to get around the statute's operation. A studio can avoid the antiprofit law's reach simply by not purchasing the criminal's story rights. Production studios, for example, fictionalize their accounts of real crimes or use the trial transcripts and court records for their information. ${ }^{132}$ Since the studio neither purchases story rights nor provides the criminal royalties, these deals are beyond the reach of the statute. They also do not involve common-law invasions of a criminal's privacy. ${ }^{133}$ Although such deals may prevent a crime victim from being compensated for her loss, they are not repugnant to the state's purpose because such productions do not enrich the criminal either.

More troubling are instances in which the antiprofit law should operate but currently does not. For example, some television producers have avoided the statute's provisions by contracting with the criminal's family or an intermediary who has purchased the crimmal's story rights instead of dealing with the crimmal himself. ${ }^{134}$ The Califorma statute

131. Snider, supra note 73, at 32. One Los Angeles executive, who "packages" story deals for television, said it was a matter of ethics for the networks. Id.

132. Id. at 31 .

133. Under the common law, a convicted criminal is a "public figure" who has become part of " the public scene through her conduct, despite neither seeking nor conseuting to publicity. RESTATEMENT (SECOND) OF TORTS, § 652D comment b (1977) (anyone who leaves herself open to the public eye cannot recover for invasion of privacy).

134. The story rights to the Reverend Thomas Bird's story were obtained through deals with Bird's family. Snider, supra note 73, at 32. Rights to fugitive Claude Dallas' story were purchased by CBS from an author who originally purchased Dallas' story. Id. at 31 . This followed CBS' practice of not dealing with the criminal at all, but " "directly with the packager." "Id.

In New York, a similar deal between Simon \& Schuster and the owner of Michele Sindona's story rights (convicted for soliciting the murder of the lawyer appointed to liquidate the assets of his failed Italian banks) has resulted in litigation. The New York Crime Victims Board claims the deal is a subterfuge designed to skirt the law, and Simon \& Schuster is challenging the New York antiprofit statute's constitutionality. See generally N.Y. State, Publishers Square Off over Ex- 
covers all fees, royalties, or other consideration given a felon for "the sale of the rights to materials." 135 Therefore, whether or not the money that the felon receives comes directly from a deal he made with a studio or through an intermediary's contract with a studio, that money should be subject to the statute. ${ }^{136}$

Likewise, the statute may be undermined by victims simply because they are unaware of its existence or the availability of funds in the trust. The statute currently contains no provision for giving notice to a crime victim of the availability of the constructive trust remedy in her case. ${ }^{137}$ It could, however, be straightforwardly amended to provide for notice of the constructive trust remedy to the victim and the convicted criminal upon entry of judgment against the defendant. Providing this notice could avoid situations in which an express trust containing book and movie proceeds is not established because neither the victim nor the state brings an action against the criminal. The State Board of Control, the agency in charge of the state's crime victims restitution program, could also provide information about the antiprofit laws in its victims compensation program. Since the statute provides a private as well as a state cause of action, ${ }^{138}$ private enforcement of the statute through a bettereducated victim should be encouraged.

\section{IV}

\section{CONCLUSION}

In establishing its antiprofit law, California has been sensitive to both the victim's and the criminal defendant's needs. The statute provides the victim with a separate cause of action for the recovery of profits unjustly earned at his expense, while allowing the criminal to use a portion of these profits for his defense, fines, and court-imposed restitution.

Mobster's Book Profits, Wash. Post, Aug. 18, 1987, at A5, col. 1; Book Set on Sindona, Italian Banker, N.Y. Times, Mar. 26, 1986, at C15, col. 4 (noting that the publisher's contract with the author, not the criminal, includes a provision allowing the author to interview the criminal).

135. CAL. Civ. Code $\S 2225($ a)(9) (West Supp. 1988).

136. For example, Jeffrey MacDonald will receive $40 \%$ of all proceeds from the sale of motion picture, television and theatrical rights to his story. See Memorandom of Points and Authorities in Support of Application for Temporary Restraming Order and Order to Show Cause re Preliminary Injuction at 6, Kassab v. MacDonald, No. C 672056 (Cal. Super. Ct. L.A. County filed Jan. 8, 1988). Such profits are within the scope of the statute even though NBC did not contract directly with MacDonald.

137. Compare the New York statute, which includes notice by publication upon deposit of funds into the escrow account and every six months thereafter for the five-year escrow period. N.Y. EXEC. LAw § 632-a(2) (McKinney 1982). Several other states provide notice to the victim or his representative concerning the presence of available funds. See ALA. CoDE $\S 41-9-81$ (1982); ILL. ANN. STAT. ch. 70, para. 405 (Smith-Hurd Supp. 1987); Iowa CODE ANN. $\$ 910.15$, subp. 2 (West Supp. 1986); MiNN. STAT. ANN. \$611A.68(3) (West 1987).

138. See supra text accompanying notes 30-39. 
The statute prevents the criminal's unjust enrichment without infringing upon his constitutional interests in speech and expression.

The California antiprofit legislation thus presents a sound solution to the unequal rewards given the criminal by our mass-media society. Victimized once at the hands of the wrongdoer, the victim should not be victimized again by the financial rewards paid to the criminal for the story of his crime. As the price for crime stories has risen, those who have paid the inost-the victims-are finally compensated for their unwanted role in the criminal's story. 
